\title{
Study of the combining adsorption-microfiltration process for the treatment of coloured waters
}

\author{
ABDELLAH. ADDAOU ${ }^{a}$, ALI. LAAJEB ${ }^{a}$, AHMED LAHSINII, JILALI. BENTAMA ${ }^{a}$, MIGUEL A. RODRIGUEZ $^{\mathrm{b}}$ \\ aLaboratoire des Sciences et du Technologie des Génies des Procédés Ecole Supérieure de Technologie Département Génie des Procédés \\ Route d'Imouzzer B.P 2427 Fès, Maroc \\ bInstituto de Cerámica y Vidrio (CSIC), C/ Kelsen 528049 Madrid, Spain. mar@icv.csic.es
}

\begin{abstract}
Generally textile effluents are highly coloured, contain non-biodegradable compounds and they have high content of solid wastes, comprising fibres and paper wastes. The discharge of such effluents in the environment is worrying for both toxicological and esthetical reasons. The aim of the present work is to study the performances of the combining microfiltration-adsorption process for the treatment of coloured waters. Methylene Blue (MB) was used as model compound. The effects of significant operating parameters such as transmembrane pressure (TMP) and bentonite concentration on the process performance characterized by flux and rejection factor were investigated. Experiments carried out with Methylene Blue solutions confirmed the potential of this combined process for the treatment of dyed waters.
\end{abstract}

keywords: Bentonite, clay, Methylene Blue, adsorption, microfiltration

Estudio del proceso combinado de adsorcion-microfiltracion en el tratamiento de aguas coloreadas

Normalmente los efluentes de la industria textil están coloreados y contienen compuestos no biodegradables además de residuos sólidos, fibras y residuos de papel. La liberación de tales efluentes al ambiente es preocupante tanto por razones estéticas como toxicológicas. El propósito del presente trabajo es realizar el estudio de las prestaciones del proceso combinado de adsorción-microfiltración para el tratamiento de aguas coloreadas. Se utilizó Azul de Metileno como compuesto tipo. La influencia de parámetros de operación tales como Presión transmembrana y la concentración de bentonita en el comportamiento del proceso, caracterizado por el flujo del permeado y el factor de retorno que fueron los parámetros estudiados. Los experimentos realizados con las soluciones de Azul de Metileno han confirmado el potencial del proceso combinado para el tratamiento de las aguas teñidas.

Palabras clave: Bentonita, arcilla, Azul de Metileno, Adsorción, Microfiltración

\section{INTRODUCTION}

Many industrial processes use different synthetic chemical dyes for various purposes. Effluents coming out from these industries are highly contaminated, resulting in major environmental problems. Generally textile effluents are highly coloured, contain non-biodegradable compounds and they have high content of solid wastes, comprising fibres and paper wastes.

The discharge of these wastewaters not only damages the aesthetic nature, but also may be toxic to aquatic life and people $[1,2]$. So these waste water need to be treated before disposal. Many methods are available for the removal of pollutants from water, the most important of which are biodegradation, flocculation-coagulation and adsorption [3-5]. Also membrane separation technologies have been used for the separation of dyes $[6,7]$. Among membrane processes, the nanofiltration is the most suitable for the decolouration of effluent from textile industry. However, its major disadvantage is the decline in permeate flux due to adsorption of organic compounds on the membrane surface [8]. On the other hand, it have been reported that fouling can significantly be reduced by adding clays minerals during ultrafiltration of organic molecules [9].

Recently adsorption of acid dyes on bentonite has been reported [10], where it was concluded that bentonite is effective in the removal of different anionic dyes.

In the present study, adsorption onto two types of natural raw materials (bentonite and local clay) is combined with microfiltration to examine the suitability of such a combined process in treating of coloured wastewaters. Methylene Blue (MB) was selected as the model compound. 


\section{MATERIALS AND METHODS}

Bentonite (B) and the clay (LC), from Morocco sources, in dry powdered form were used in this work with any further purification. They have 59 and $28 \mathrm{~m}^{2} / \mathrm{gr}$ of specific surface and 3.8 and $5 \mathrm{~mm}$ particle size respectively. Their chemical compositions have been reported elsewhere [11, 12]. The dye namely Methylene Blue (MB) with a labelled purity for more than $98 \%$ was obtained from a Fisher Scientific International Company and used as such. Solutions with different concentrations were prepared using distilled water.

Microfiltration experiments were performed, in a dynamic regime, using a membrane pilot that was designed and fabricated in our laboratory (figure 1) with a inorganic tubular membrane ( $\alpha$ alumina) of $0,4 \mu \mathrm{m}$ in pore size, 10 $\mathrm{mm}$. outer diameter, $7 \mathrm{~mm}$. inner diameter and $250 \mathrm{~mm}$. length (T1-70. Pall Exekia. France). The crossflow velocity was 0.5 $\mathrm{m} / \mathrm{s}$ approximately, and the experiments were carried out at $25^{\circ} \mathrm{C}$. Sometimes (for long term experiments) the solution was cooled in order to maintain the temperature constant. Transmembrane pressure changed in different experiments from 1 up to 3 bars.

The experiments in order to compare the capacity and permeability of system using Bentonite or a local Clay have been carried out using an used-recycled membrane support. This fact has been done in order to avoid the fouling effect into the results. For this reason permeability for this experiment will be lower than in the rest of the experiments.

The concentrations of $\mathrm{MB}$ in permeate were determined using Jenway 6505 UV/Vis. Spectrophotometer. All measurements were done at the wave length corresponding to maximum absorbance of $665 \mathrm{~nm}$.

\section{RESULTS AND DISCUSSION}

The performance of microfiltration system alone (without adding Bentonite to the feed solution) was tested at the beginning of the experiments using a $\mathrm{MB}$ concentration of $100 \mathrm{mg} / \mathrm{l}$, but no notable rejection of the dyes was recorded. The effect of bentonite addition on the flux and composition of permeate was examined by varying the dye concentration from 20 to $300 \mathrm{mg} / 1$ while fixing the feed temperature $\left(25^{\circ} \mathrm{C}\right)$, transmembrane pressure (TMP) and bentonite concentration (figures 2 and 3).

Increasing the dye concentration from 20 to $100 \mathrm{mg} / 1$ appears to have little effect on the rejection of MB (100\%). However, varying concentration beyond $100 \mathrm{mg} / 1$ led to a sharp decrease in the rejection factor. From this figure the maximum retention capacity of the system can be estimated as $10 \%$ of the total weight of bentonite. This behaviour is compatible results reported in the literature regarding the effect of bentonite addition on the removal of MB [13].

The variations of permeate flux with step increments of transmembrane pressures (TMP) were studied (figure 4). In this case, when the flux decreases dramatically (more than $30 \%$ ) the pressure was increased in order to re-establish the flux.

For the first TMP of 1.5 bar, the permeate flux showed sharp reduction from 275 to $150 \mathrm{l} / \mathrm{hm}^{2}$. By increasing the TMP the value of permeate kept on increasing. Once the TMP arrives to 3 bar, the permeate flux reached a maximum value of $370 \mathrm{l} / \mathrm{hm}^{2}$. It also can be observed than, once the increment of TMP arrives to 2 bar or higher, and when the flux is stabilized, a near-constant value (they are into the error limit) of flux $\left(\sim 200 \mathrm{l} / \mathrm{hm}^{2}\right)$ is obtained.

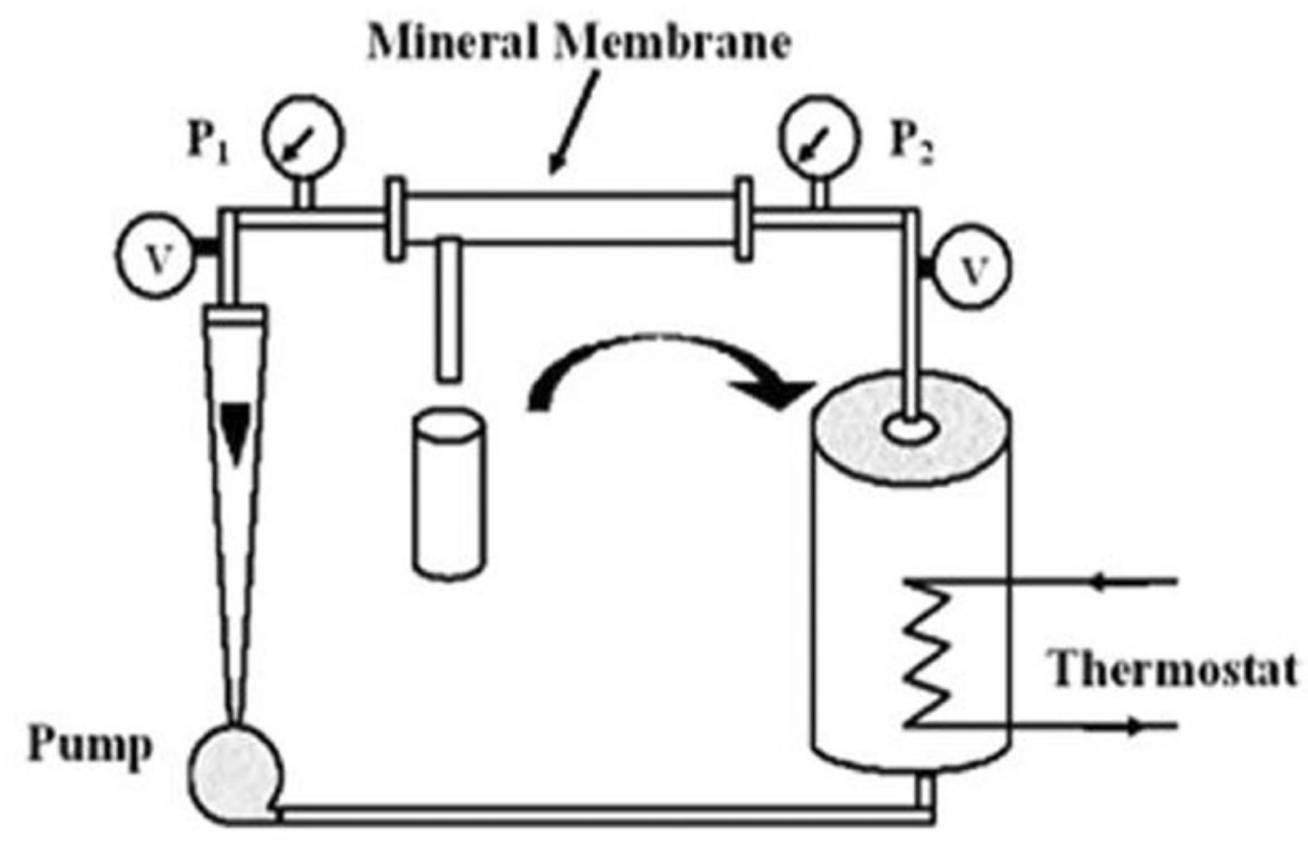

Fig. 1: Schematic drawing of experimental setup 
At this stage the flux shows its independence of TMP. It can be explained considering the formation of a Bentonite layer on the membrane surface. When the TMP increase, this layer compacts, decreasing the porous volume and size, and consequently its permeability. Nevertheless, this compaction has a limit that probably takes place at TMP near 2 bar. For this reason the use of higher pressures have no sense.

At the descending phase, the evidence of hysteresis was significant after TMP was decreased. The permeate flux was far below the one recorded at the same TMP ascending phase.

In addition, the effect of the nature of adsorbent on the retention of $\mathrm{MB}$ was studied by comparing the filtration of dye solutions in presence of Bentonite and local clay (figure 5). The retention of $\mathrm{MB}$ obtained are 100 and $86 \%$ in presence $\mathrm{B}$ and $\mathrm{LC}$ respectively. This may result from a relative difference of their microstructural characteristics.

Considering the flux two facts can be stated:

- First that the flux reach a steady state in less than 5 minutes, when Bentonite is used, while it remains decreasing when the Local Clay is used.

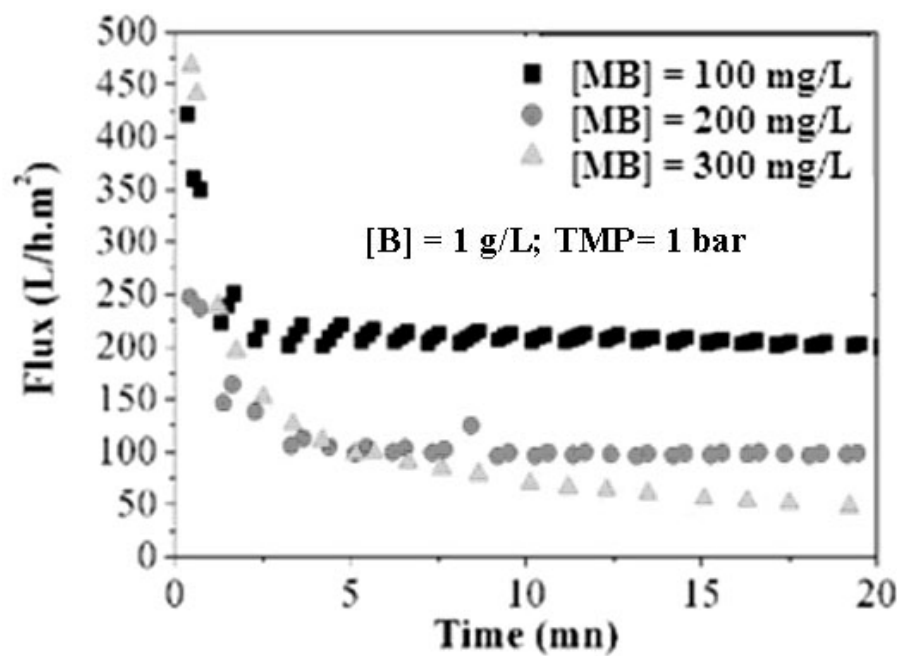

Fig. 2: Microfiltration of bentonite suspension in presence of MB.

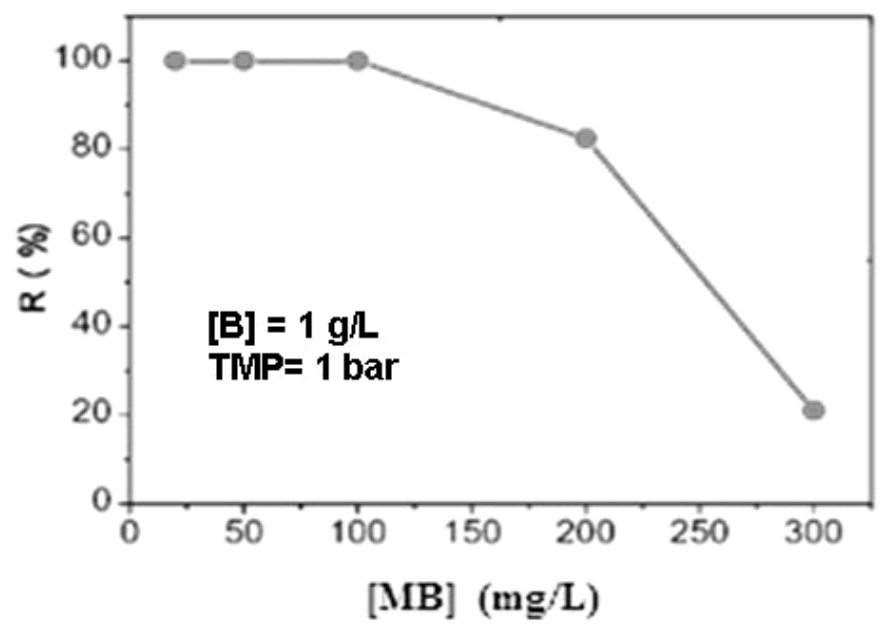

Fig. 3: Evolution of the rate of retention in function of the [MB].
- A higher flux (near 20\% after 20 minutes) is observed when local clay is used. This important result must be studied in the future, because the membrane output is an important parameter in this kind of systems.

\section{CONCLUSION}

This study was concerned primarily with investigating of microfiltration-adsorption as a single step treatment process for the removal of Methylene Blue dye from aqueous solution. The hybrid process utilizes the capabilities of clay to adsorb dyes and the capabilities of microfiltration to remove colloids. The addition of Bentonite to the feed solutions was found to increase the rejection coefficient of Methylene Blue, but considerably deteriorate the permeate flux.

The maximum retention capacity of the Bentonite measured has been $10 \%$ of the total weight of this material. Nevertheless the use the combined system (Microfiltrationadsorption) gives the possibility to recycle the system easily.

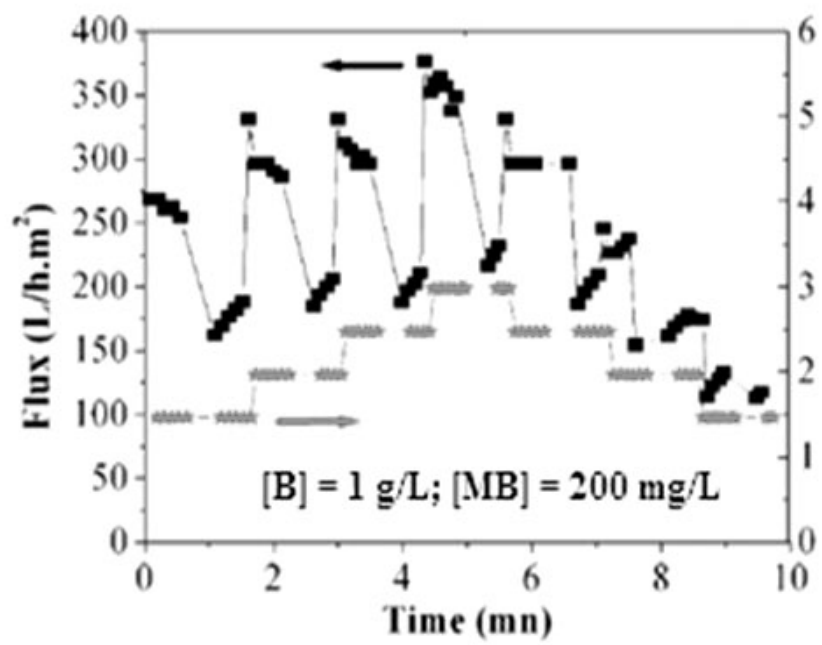

总

Fig. 4: Variation of permeate flux with time under step increment of TMP.

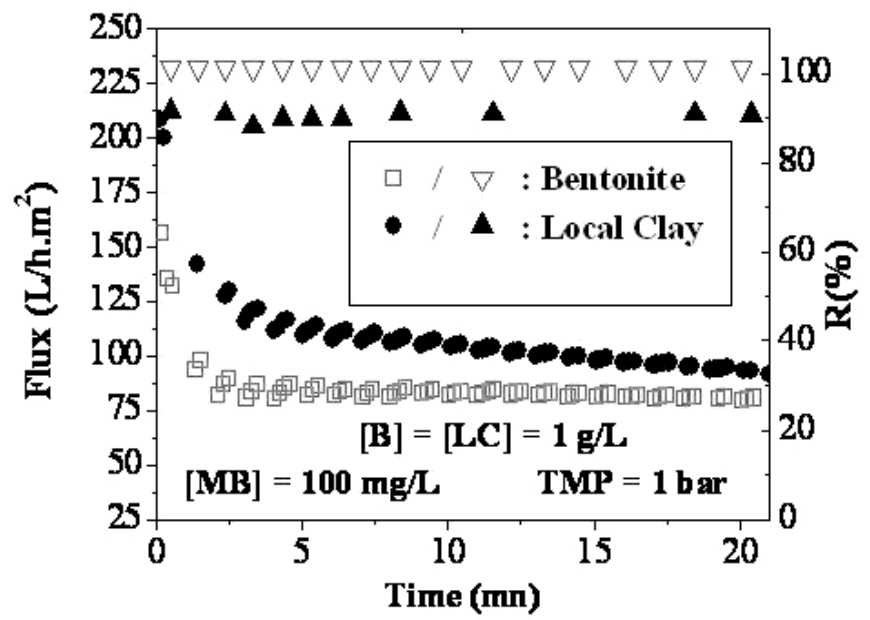

Fig. 5: Effect of the nature of material on the rate of retention 
The permeability reaches a maximum, when the TMP increase at values of 2 bar, or higher. For this reason the use of higher pressures has not a negligible effect in this system.

Experiments run with Methylene Blue solutions confirmed the potential dye rejection of this combined process for the treatment of dyed waters.

\section{ACKNOWLEDGEMENTS}

This work was financially supported by the CNRST and the Ecole Superieure de Technologie de Fes (Morocco) and the CSIC (Spain) through the project $\mathrm{N}^{\circ}$ 2009MA0008.

\section{REFERENCES}

[1] S.S. Nawar, H.S. Doma, Removal of dyes from effluents using low cost agricultural by- products, Sci. Total Environ. 79 (1989) 271-279.

[2] S.J. Allen, G. Mckay, J.F. Porter, Adsorption isotherms models for basic dye adsorption by peat in single and binary component systems, J. Colloid Interface Sci. 280 (2004) 322-333.

[3] G.M. Walker, L.R. Weatherly, biodegradation and biosorption of acid anthraquinone dye, Environ. Pollut. 108 (2000) 219-223.

[4] V. Golob, A. Vinder, M. Simonic, Efficiency of the coagulation flocculation method for the treatment of dyebath effluents, Dyes and pigments 67 (2005) 93-97.
[5] M. D. Machado, M.V.M. Soares, E.V. Soares; Removal of Chromium, Copper, and Nickel from an Electroplating Effluent Using a Flocculent Brewer's Yeast Strain of Saccharomyces cerevisiae. Water Air Soil Pollut. 212 (2010) 199-204.

[6] S. Chakraborty, S. De, J.K. Basu, S.Dasgupta, Treatment of a textile effluent: application of a combination method involving adsorption and nanofiltration, Desalination 185 (2005) 399-409.

[7] C. Fersi, L. Gzara, M. Dhahbi, Treatment of textile effluents by membrane technologies, Desalination 185 (2005) 73-85.

[8] B. Vander Bruggen, B. Daems, D. Wilms, C. Vandecasteele, Mechanisms of retention and flux decline for the nanofiltration of dye baths from the textile industry, Sep. Purif. Technol. 22-23 (2001) 519-528.

[9] A.Kryvoruchko I. Atamanenko, B. Kornilovich; A role of the clay minerals in the membrane purification process of water from Co (II)- ions ; Sep. Purif. Technol. 25 (2001) 487-492.

[10] S. Qiao, Q. Hu, F. Haghseresht, X. Hu, G.Q. Lu. An investigation on the adsorption of acid dyes on bentonite based composite adsorbent. Sep. Purif. Technol. 67 (2009) 218-225.

[11] A. Lahsini, A. Addaou, T. Amiri, Caracterisation Physico-Chimique d'une bentonite destinée à l'adsorption des protéines. J. Cat. Env. IV (2004) 145149

[12] A. Lahsini, J. Bentama, A. Addaou, M. Rafiq, Caractérisation PhysicoChimique et étude du frittage d'une argile destinée à l'élaboration de membranes de filtration tangentielle. J.Chim. Phys 95 (1998) 1001- 1019

[13] Al-Aseh S, Banat F, Abu-h L. The removal of methylene blue dye from aqueous solutions using actived and non actived bentonite, Adsorption Sci. Technol 21 (2003) 451-462.

Recibido: $12 / 11 / 2010$

Aceptado: 4/10/2011 